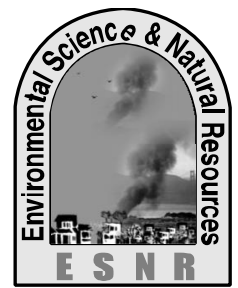

\title{
Selecting Appropriate Cotton Based Cropping Pattern for Increasing Cropping Intensity in Bangladesh
}

\author{
S. Kundu, K. Hassan*, S. M. J. B. Alam and M. F. Uddin \\ Cotton Development Board, Regional Office, Jessore \\ "Corresponding author: khasancdb@gmail.com
}

\begin{abstract}
The experiment was conducted at Cotton Research, Training and Seed Multiplication Farm, Jagodishpur, Chowgacha, Jessore initiated June 19, 2015 for the cropping season 2015-16 to observe the performance of cotton based cropping system including total three crops in a year. The other crops were i) relay wheat $\ddot{i}$ mungbean and ii) relay lentil $\ddot{i}$ mungbean. Four cotton varieties CB-12, CB-13, CB-14 and CB Hybrid-1 were sowed in a RCBD design with three replications. Seed cotton yield was significantly different among the varieties. The highest seed cotton yield $(2519.3 \mathrm{~kg} / \mathrm{ha})$ was obtained from CB Hybrid-1 and the lowest $(2112.37 \mathrm{~kg} / \mathrm{ha}$ ) seed cotton was produced by CB-13. The highest BCR (1.31) was observed in cotton (CB Hybrid-1) ïrelay lentil Ï mungbean cropping pattern and the lowest BCR (1.10) was observed in Cotton (CB-13) ï relay wheat ï mungbean cropping pattern. The finding infers that cotton ï relay lentil mungbean cropping pattern might have the potentiality to increase cropping intensity in Bangladesh.
\end{abstract}

Key words: Cropping pattern, Relay, Seed cotton

\section{Introduction}

Cotton is a major agricultural crop, grown in more than 60 countries of the world providing employment and income to the millions of people. It is a multipurpose crop and provides raw materials for the industry (Hossain et al., 2007). Bangladesh has a glorious historical record in growing superfine quality cotton. In the past `Muslinôwas popular and famous throughout the world. At present more than 152 yarn and textile mills are running in Bangladesh. Every year 6 to 7 million bales of medium and long staple cotton fiber are used in these mills (Anonymous, 2001; Rasel et al., 2007), but our production is only 100,000 to 150,000 bales. Maximum cotton is imported from abroad at the expense pf costly foreign currency. Therefore, there is a great scope to increase the cotton production in Bangladesh (Hossain et al., 2007).

Upland cotton is being cultivated commercially in Bangladesh. It has a potential benefit as a cash crop. Six to seven month are required for growing cotton (JuneJuly to February). Cotton is profitable as a sole crop but it will be more profitable to the farmers if they can introduce relay wheat, lentil or mung bean cropping with cotton in a cropping pattern. This relay cropping system can help to improve soil health and generate more income to the farmers. However, rare works in this country on cotton based cropping pattern have been done to fit cotton in local cropping pattern or to developed cotton based cropping pattern (Amin, 2008; Mian and Mandol, 2004). Farming systems in Bangladesh are dominated by different varieties of crops. Cropping system or cropping patterns are adjusted to natural resource conditions (Sultana et al., 2008). It is needed to take integrated efforts in future research programs on the development of triple cropping in a pattern to improve or sustain the productivity. The productivity of rice - wheat systems in Bangladesh is observed declining every year. This can be done by growing dual or triple purpose crops and developing appropriate mixed, intercropping or relay cropping systems; development of integrated nutrient (organic, green manure and inorganic) management practices for sustainable system productivity; long term monitoring of fertilizer use and the soil fertility for the system (Elahi et al., 1995).

Cotton is one of the most important commercial crops in the world but it is not popular in Bangladesh due to the top priority given for food crops. Much works have been done on cotton as a sole crop or mono crop but there is scarcities of information on cotton based intercropping/ relay cropping or cropping patterns. Therefore, this research work is aimed at relay cropping wheat, lentil and mung bean with cotton for better productivity and efficient utilization of land for sustainable cotton cultivation in Bangladesh. 


\section{Materials and Methods}

The experimental land was prepared by disc harrowing followed by mixing organic manure (cow dung) with soil during harrowing on 19 June 2015. The layout of the experiment was done as per statistical design. Ploughing was done followed by laddering in order to break clods as well as level the land. The experiment was conducted in Cotton Research, Training and Seed Multiplication Farm, Jagodishpur, Jessore in a randomized complete block design with three replications. There were 12 unit plots of each $10 \mathrm{~m} \mathrm{X} 10 \mathrm{~m}$. The treatments were $\mathrm{T}_{1}$ : CB12, $\mathrm{T}_{2}$ : CB-13, $\mathrm{T}_{3}$ : CB-14 and $\mathrm{T}_{4}$ : CB Hybrid-1. AS relay crop wheat variety was BARI-25, lentil was BARI-5 and mung bean was BARI-5. Cropping systems were used 1) cotton-relay wheat-mung bean and 2) cotton-relay lentil- mung bean.

\section{Fertilizer application}

1: Dose of fertilizer application for cotton

\begin{tabular}{|c|c|c|c|c|c|c|}
\hline \multirow{3}{*}{$\begin{array}{l}\text { Name of } \\
\text { fertilizer }\end{array}$} & \multicolumn{5}{|c|}{ Amount of fertilizer ( $\mathrm{kg} / \mathrm{ha}$ ) } & \multirow[t]{3}{*}{ Comments } \\
\hline & \multirow{2}{*}{$\begin{array}{c}\text { Total } \\
\text { amount }\end{array}$} & \multirow{2}{*}{$\begin{array}{c}\text { Basal } \\
\text { dose }\end{array}$} & \multicolumn{3}{|c|}{ Side dressing } & \\
\hline & & & $1^{\text {st }}($ 20DAS) & $2^{\text {nd }}(40 D A S)$ & $3^{\text {rd }}(60 D A S)$ & \\
\hline Urea & 250 & 36 & 62 & 50 & 50 & \\
\hline TSP & 225 & 150 & & 75 & & \\
\hline Mop & 265 & 90 & 60 & 58 & 57 & \\
\hline Gypsum & 105 & 45 & 30 & 30 & & \\
\hline Zinc & 15 & & 15 & & & \\
\hline Boron & 20 & & 15 & 5 & & \\
\hline Magsulphate & 15 & & 15 & & & \\
\hline Cow dung & 4500 & & & & & \\
\hline & & & & & & \\
\hline
\end{tabular}

2: Dose of fertilizer application for wheat

\begin{tabular}{|c|c|c|c|c|}
\hline \multirow{2}{*}{ Name of fertilizer } & \multicolumn{3}{|c|}{ Amount of fertilizer ( kg/ha ) } & Comments \\
\cline { 2 - 5 } & \multirow{2}{*}{$\begin{array}{c}\text { Total } \\
\text { amount }\end{array}$} & \multicolumn{2}{|c|}{ Side dressing } & \\
\cline { 3 - 5 } & & Basal & (23 DAS) & \\
\hline Urea & 150 & 45 & - & - \\
\hline TSP & 150 & 150 & - & - \\
\hline Gypsum & 95 & 95 & & \\
\hline Boron & 6 & 6 & \\
\hline
\end{tabular}

3: Dose of fertilizer application for lentil

\begin{tabular}{|c|c|c|c|c|}
\hline \multirow{2}{*}{ Name of fertilizer } & \multicolumn{3}{|c|}{ Amount of fertilizer ( kg/ha ) } & Comments \\
\cline { 2 - 4 } & \multirow{2}{*}{$\begin{array}{c}\text { Total } \\
\text { amount }\end{array}$} & \multicolumn{2}{|c|}{ Side dressing } \\
\cline { 3 - 5 } & & $\begin{array}{c}\text { Final land } \\
\text { preparation }\end{array}$ & \\
\hline Urea & 30 & 15 & 15 \\
\hline TSP & 100 & 100 & - \\
\hline MOP & 40 & 40 & & - \\
\hline Gypsum & 55 & 55 & & - \\
\hline Boron & 12 & 12 & & - \\
\hline
\end{tabular}




\section{Sowing of seeds}

\section{Cotton}

Cotton seeds were sown on 20 June, 2015 at the rate of $15 \mathrm{~kg}$ seed/ha. The seed was sown by hand, keeping a distance of $35 \mathrm{~cm}$ from plant to plant and row to row distance was $90 \mathrm{~cm}$. All seeds were sown at the depth of 2 to $3 \mathrm{~cm}$ from the surface soil and covered manually with loose soil.

\section{Wheat and lentil}

At the $2^{\text {nd }}$ harvesting stage of cotton, lentil seeds were sown on 03 December, 2015 at the rate of $45 \mathrm{~kg} / \mathrm{ha}$ in between cotton rows with little irrigation. On the other hand wheat seeds were sown on 11 December, 2015 at the rate of $90 \mathrm{~kg} / \mathrm{ha}$ in between cotton rows with little irrigation.

\section{Mung bean}

After harvesting of wheat and lentil, mung bean seeds were sown on $05 \mathrm{March}, 2016$ at the rate of $44 \mathrm{~kg} / \mathrm{ha}$ with tillage and light irrigation.

\section{Irrigation}

Two irrigations were applied for cotton, first irrigation at 88 DAS and second at 123 DAS and twice for wheat at 20 and 40 DAS.

\section{Weeding}

Three weeding were done during the whole growing period of cotton, which was done at 24, 46 and 63 DAS accordingly and two weeding was done for wheat before irrigation and single weeding was done for lentil.

\section{Insect and pest control}

Integrated pest managements such as mechanical and chemical control measures were applied specially for cotton. Five sprays were applied when the pest levels exceeds the relevant threshold at regular weekly counts. The insecticides which are recommended for the use of cotton were used to suppress the pest below ETL level. The systemic insecticides were used for sucking pest and contact insecticides for chewing pests. Fungicides were used for cotton, wheat and lentil crop to prevent diseases.

\section{Harvesting \\ Cotton}

Seed cotton picking was done three times, $1^{\text {st }}$ on last week of November, $2^{\text {nd }}$ on mid December 2015 and last picking on mid -January 2016.

\section{Wheat}

Wheat was harvested on 29 February, 2016.

\section{Lentil}

Lentil was harvested on mid February.

\section{Mung bean}

Mung bean was harvested on last week of May.

\section{Results and Discussion}

Mean performance of agronomic traits of cotton varieties was presented in Table-1 and Table-3. It was observed from Table-1 and Table- 3 that the average number of bolls was statistically significant at $1 \%$ level of significance. According to the result of Table- 1 the highest bolls (25.73 plant $\left.^{-1}\right)$ were produced by $\mathrm{T}_{1}$ (CB12) and the lowest (21.0 plant $\left.^{-1}\right)$ was produced by $T_{2}$ (CB-13). Similar results regarding boll number was also observed in Table-3. Average boll weight was found significant at $1 \%$ level of significance in Table-1 and Table-3. From Table-1 it was observed that the highest boll weight $\left(6 \mathrm{~g} \mathrm{boll}^{-1}\right)$ was produced by $\mathrm{T}_{4}$ treatment and lowest $\left(4.93 \mathrm{~g} \mathrm{boll}^{-1}\right)$ was produced by $\mathrm{T}_{1}$. Similar result on boll weight was also observed in Table-3. It was also revealed from Table-1 and Table- 3 that significant differences on seed cotton yield was occurred among varieties varied at $1 \%$ level of significance. $\mathrm{T}_{4}$ (CBHybrid-1) treatment produced the highest seed cotton yield (2519 $\left.\mathrm{kgha}^{-1}\right)$ and lowest yield (2112 kg ha-1) was observed in $T_{2}$ treatment (Table-1) and the same performance was observed in Table-3. Increased boll number and boll weight had a role to increase yield in $\mathrm{T}_{4}$. It might be due to genetical makeup of the cultivars. The findings are in accordance with those of Qayyum et al. (1990), Khan and Khan (1992), Rajput et al. (1993) and Qayyum et al. (1996) who had already reported variation for yield in different varieties. Performance of other traits was not significant among the varieties. From Table-2, the highest BCR (1.20) was observed in $\mathrm{T}_{4} \ddot{i}$ wheat $\ddot{i}$ mung bean relay cropping system and the lowest BCR (1.10) was observed in $T_{2} \ddot{i}$ wheat $\ddot{i}$ mung bean relay cropping system. From Table-4 the highest BCR (1.31) was observed in $\mathrm{T}_{4} \ddot{\mathrm{I}}$ relay lentil $\ddot{i}$ mung bean cropping system and the lowest BCR (1.21) was observed in $\mathrm{T}_{2}$ relay lentil $\mathrm{i}$ mung bean cropping system. 
Table 1. Varietal performance of cotton in cropping system, cotton- relay wheat- mung bean

\begin{tabular}{|l|l|l|l|l|l|l|l|l|}
\hline Treatment & NVB & NFB & $\begin{array}{l}\text { N0. of } \\
\text { PFB/ } \\
\text { plant }\end{array}$ & $\begin{array}{l}\text { Days to 1 } \\
\text { Boll Split }\end{array}$ & $\begin{array}{l}\text { No. of } \\
\text { Boll/ } \\
\text { plant }\end{array}$ & $\begin{array}{l}\text { Single } \\
\text { Boll wt } \\
(\mathrm{g})\end{array}$ & $\begin{array}{l}\text { Plant ht. } \\
(\mathrm{cm})\end{array}$ & Yield (kg/ha) \\
\hline $\mathrm{T}_{1}$ & 1.40 & 5.30 & 17.33 & 114.33 & $25.73 \mathrm{a}$ & $4.93 \mathrm{c}$ & 94.10 & $2238.43 \mathrm{c}$ \\
\hline $\mathrm{T}_{2}$ & 1.30 & 5.73 & 16.87 & 113.33 & $21.00 \mathrm{c}$ & $4.97 \mathrm{c}$ & 97.60 & $2112.37 \mathrm{~d}$ \\
\hline $\mathrm{T}_{3}$ & 1.53 & 5.50 & 18.17 & 114.00 & $23.13 \mathrm{~b}$ & $5.57 \mathrm{~b}$ & 92.43 & $2428.30 \mathrm{~b}$ \\
\hline $\mathrm{T}_{4}$ & 1.47 & 5.40 & 18.07 & 114.33 & $23.67 \mathrm{~b}$ & $6.00 \mathrm{a}$ & 98.77 & $2519.30 \mathrm{a}$ \\
\hline $\mathrm{CV}(\%)$ & 15.52 & 6.07 & 3.34 & 1.04 & 4.57 & 2.13 & 4.64 & 1.62 \\
\hline $\begin{array}{l}\text { Level of } \\
\text { significance }\end{array}$ & $\mathrm{NS}$ & $\mathrm{NS}$ & $\mathrm{NS}$ & $\mathrm{NS}$ & $* *$ & $* *$ & $\mathrm{NS}$ & $* *$ \\
\hline
\end{tabular}

Note: NS=non-significant, *significant at 5\% level, **significance at $1 \%$ level

Table 2. Yield and BCR of cotton in cropping system, cotton- relay wheat- mung bean

\begin{tabular}{|c|c|c|c|c|c|c|c|c|c|c|}
\hline \multirow[b]{2}{*}{ 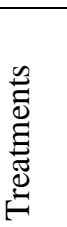 } & \multicolumn{3}{|c|}{ Yield $\left(\mathrm{kg} \mathrm{ha}^{-1}\right)$} & \multicolumn{3}{|c|}{ Expenditure $\left(\mathrm{Tk} \mathrm{ha}^{-1}\right)$} & \multicolumn{3}{|c|}{ Net income $\left(\mathrm{Tk} \mathrm{ha}^{-1}\right)$} & \multirow[t]{2}{*}{$\overline{\mathrm{BCR}}$} \\
\hline & cotton & wheat & $\begin{array}{l}\text { mung } \\
\text { bean }\end{array}$ & cotton & wheat & $\begin{array}{l}\text { Mung } \\
\text { bean }\end{array}$ & cotton & wheat & $\begin{array}{l}\text { mung } \\
\text { bean }\end{array}$ & \\
\hline$\overline{\mathrm{T}_{1}}$ & 2238 & 2509 & 1140 & 107025 & 43200 & 38570 & 10470 & 1962 & 12730 & 1.13 \\
\hline $\mathrm{T}_{2}$ & 2112 & 2530 & 1150 & 107025 & 43200 & 38570 & 3855 & 2340 & 13180 & 1.10 \\
\hline $\mathrm{T}_{3}$ & 2428 & 2540 & 1090 & 107025 & 43200 & 38570 & 20445 & 2520 & 10480 & 1.17 \\
\hline $\mathrm{T}_{4}$ & 2519 & 2517 & 1110 & 107025 & 43200 & 38570 & 25223 & 2106 & 11380 & 1.20 \\
\hline
\end{tabular}

Market rates: $\mathrm{Tk} \mathrm{kg}^{-1}$ Seed cotton $=52.50$, Wheat $=18.00$, mung bean $=45.00$

Table 3. Varietal performance of cotton in cropping system cotton- relay lentil- mung bean

\begin{tabular}{|l|l|l|l|l|l|l|l|l|}
\hline Treatment & NVB & NFB & $\begin{array}{l}\text { N0. of } \\
\text { PFB/ } \\
\text { plant }\end{array}$ & $\begin{array}{l}\text { Days to } \\
1^{\text {st Boll }} \\
\text { Split }\end{array}$ & $\begin{array}{l}\text { No. of } \\
\text { Boll/ } \\
\text { plant }\end{array}$ & $\begin{array}{l}\text { Single } \\
\text { Boll wt } \\
(\mathrm{g})\end{array}$ & $\begin{array}{l}\text { Plant ht. } \\
(\mathrm{cm})\end{array}$ & Yield (kg/ha) \\
\hline T1 & 1.63 & 5.03 & 17.47 & 117.67 & $25.73 \mathrm{a}$ & $5.27 \mathrm{c}$ & 99.47 & $2352.03 \mathrm{~b}$ \\
\hline T2 & 1.50 & 5.73 & 17.60 & 114.67 & $21.00 \mathrm{c}$ & $5.47 \mathrm{c}$ & 100.77 & $2235.67 \mathrm{c}$ \\
\hline T3 & 1.77 & 5.47 & 17.27 & 113.00 & $23.13 \mathrm{~b}$ & $5.83 \mathrm{~b}$ & 99.67 & $2280.07 \mathrm{bc}$ \\
\hline T4 & 1.13 & 5.47 & 17.50 & 115.33 & $23.67 \mathrm{~b}$ & $6.37 \mathrm{a}$ & 91.50 & $2495.00 \mathrm{a}$ \\
\hline CV $(\%)$ & 17.74 & 8.52 & 4.89 & 1.41 & 4.57 & 2.31 & 4.84 & 2.05 \\
\hline $\begin{array}{l}\text { Level of } \\
\text { significance }\end{array}$ & NS & NS & NS & NS & $* *$ & $* *$ & NS & $* *$ \\
\hline
\end{tabular}

Note: NS=non-significant, **significant at $1 \%$ level

Table 4. Yield and BCR of cotton based relay cropping system cotton- relay lentil- mung bean

\begin{tabular}{|c|c|c|c|c|c|c|c|c|c|c|}
\hline \multirow[b]{2}{*}{ 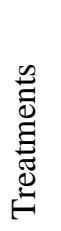 } & \multicolumn{3}{|c|}{ Yield $\left(\mathrm{kgha}^{-1}\right)$} & \multicolumn{3}{|c|}{$\begin{array}{c}\text { Expenditure } \\
\left(\text { Tkha }^{-1}\right)\end{array}$} & \multicolumn{3}{|c|}{$\begin{array}{l}\text { Net income } \\
\left(\text { Tkha }^{-1}\right)\end{array}$} & \multirow[t]{2}{*}{ BCR } \\
\hline & cotton & lentil & $\begin{array}{l}\text { mung } \\
\text { bean }\end{array}$ & cotton & lentil & $\begin{array}{l}\text { mung } \\
\text { bean }\end{array}$ & cotton & lentil & $\begin{array}{l}\text { mung } \\
\text { bean }\end{array}$ & \\
\hline $\mathrm{T}_{1}$ & 2352 & 875 & 1195 & 107025 & 42400 & 38570 & 16455 & 18850 & 15205 & 1.27 \\
\hline $\mathrm{T}_{2}$ & 2235 & 834 & 1155 & 107025 & 42400 & 38570 & 10313 & 15980 & 13405 & 1.21 \\
\hline $\mathrm{T}_{3}$ & 2280 & 810 & 1170 & 107025 & 42400 & 38570 & 12675 & 14300 & 14080 & 1.22 \\
\hline $\mathrm{T}_{4}$ & 2495 & 867 & 1210 & 107025 & 42400 & 38570 & 23963 & 18290 & 14080 & 1.31 \\
\hline
\end{tabular}

Market rates: $\mathrm{Tk} \mathrm{kg}^{-1}$ Seed cotton $=52.50$, Lentil $=70.00$, mungbean $=45.00$ 


\section{Conclusions}

Cotton (CB Hybrid-1) - relay lentil ï mungbean showed the best performance regarding yield and BCR. CBHybrid-1 produced the highest seed cotton in the relay cropping system and the highest BCR was obtained from cotton (CB-hybrid-1) ï relay lentil $\ddot{i}$ mungbean cropping system. Including of three crops in cotton based cropping system is new. This cropping system should be commenced earlier and it may have the possibility to get two more crops in a year after harvesting seed cotton.

\section{References}

Anonymous. 2001. Cotton Production Program. Cotton Development Board, Khamarbari, Farmgate, Dhaka-1215. P.105.

Elahi, N. E. , N. U. Ahmed, M. M. Alam, A. M. Bhuiyan, P.C. Bhattacharya, M. R. Islam, M. U. Ghani, T. Islam and M. Nuruzzaman. 1995. Achievements of rice wheat system research in Bangladesh. Rice Research Institute. Proceedings of the workshop. Sustainability of rice wheat systems in Bangladesh. P. 43-59.

Hossain, M. M., S. M. A. Hossain and M. A. Ahad. 2007. Abundance of major pest and predator on different varieties of cotton in Bangladesh. MS Thesis. Dept. of Entomology, Hajee Md.Danesh Sci. and Tech. Univ., Dinajpur, Bangladesh.
Khan, K. and S. Khan, 1992. The effects of dates of planting on the yield of promising cotton cultivars under climatic conditions of D.I. Khan. The Pakistan Cottons, 36: 291033.

Qayyum, S.M., A.H. Ansari, N.A. Chaudhary and M.M.A. Baig, 1990. Seed cotton yield its components and their interrelation response of six upland cotton cultivars with regard of sowing dates. The Pakistan Cottons, 34: 59 ï 73.

Qayyum, S.M., A.S.A. Arain and A.H. Ansari, 1996. Response of some cotton genotypes to early, medium and late sowing times. The Pakistan Cottons, 40: $4 і 11$.

Rajput, M.K.K., A.H. Ansari, A.G. Magsi, S.A. Rao and A.K. Akbani, 1993. Growth and yield response of cotton varieties to different sowing dates. Pakistan J. Agric. Engg. Vet. Sci., 9: $74 і ̈ 80$.

Rasel N.A., S. A. M. A. Hossain and M.A. Ahad. 2007. Effect of some systematic insecticides against major sucking pest of cotton and their predators. MS Thesis. Dept. of Entomology., Hajee Md. Danesh Sci. and Tech. Univ., Dinajpur, Bangladesh

Sultana, B. S. , M. H. Mian and M. M. Rahman. 2008. Effect of liming of soil properties and yield of wheat. MS. Dept. of soil sci., Hajee Md. Danesh Sci. and Tech. Univ., Dinajpur, Bangladesh. 